\title{
Analysis of Optimal Portfolio Selection and Portfolio Performance Evaluation on LQ45 Shares
}

Suroto*

Business and Economics Faculty, Universitas 17 Agustus 1945 Semarang, Indonesia

DOI: $10.36348 /$ sjef.2020.v04i12.004 $\quad$ | Received: 19.11.2020 | Accepted: 02.12.2020 | Published: 13.12 .2020

*Corresponding author: Suroto

\section{Abstract}

The purpose of this study is to assess portfolios that have been formed using a calculation model that calculates total risk and also to find out portfolios formed from companies listed on the LQ 45 Index on the IDX for the period February-July 2020. This research is a census research in which the population is all company shares that are consistently included in the LQ-45 index for the period February-July 2020. The data used is derived from secondary data, in the form of daily closing stock prices and daily closing composite stock price index obtained from data Indonesia Exchange Monthly Statistics and data on interest rates for Bank Indonesia Certificates for the period 30 April - 30 June 2020. The results showed that there were 9 stocks formed from 45 LQ45 stocks. The proportion of shares formed from LQ45 shares is TOWR of 0.263 , SCMA of 0.175 , BTPS of 0.174 , SMGR of 0.123 , JSMR of 0.148 , EXCL of 0.048 , CPIN of 0.047 , INCO of 0.007 and ASII of 0.014. The portfolio performance formed from LQ-45 is better than the Stock Price Index G, this is indicated by the LQ-45 portfolio sharpe index figure of 0.3902 and the JCI has a sharpe index of 0.0804 .

Keywords: Single Index Model, Sharpe Index, LQ-45, Efficient Portfolio, Optimal Portfolio, Portfolio Performance.

Copyright (C) 2020 The Author(s): This is an open-access article distributed under the terms of the Creative Commons Attribution 4.0 International License (CC BY-NC 4.0) which permits unrestricted use, distribution, and reproduction in any medium for non-commercial use provided the original author and source are credited.

\section{INTRODUCTION}

Investment activities in the business world are closely related. Investment is a commitment to a number of funds carried out at this time, to obtain a number of returns in the future [1]. Investors tend to prefer to invest in the capital market because it is a long-term investment [2].

The capital market is one of the facilities for investing in the financial sector that is attractive to investors. This is because the capital market gives investors the freedom to choose securities traded in the capital market in accordance with the wishes of investors. Apart from that, the capital market also promises greater returns to investors. To maximize the return that will be obtained, investors usually do not only invest in one stock. However, investors will invest their funds in several stocks with the aim of minimizing risk. Therefore, the formation of a portfolio and the selection of an optimal portfolio is needed.

A portfolio is a collection of financial assets in a unit that is held or arranged by an investor, investment company, or financial institution. Husnan, explains that a portfolio is a set of investments. Meanwhile, the optimal portfolio is the portfolio that provides the combination of the highest return with the lowest risk [4].

The Markowitz model and the single index model are optimal portfolio formation and selection models. The Markowitz model emphasizes maximizing the expected return and minimizing risk, while the Single Index Model can simplify calculations in the Markowitz model by providing the input parameters required in the calculation of the Markowitz model [4]. The Single Index model was chosen because risk-free assets were not considered in the Markowitz model [5], while the optimal portfolio would be different if riskfree loans and deposits were not available [4].

Hartono, states that optimal portfolio performance can decline due to bad market conditions. However, the stocks in the LQ-45 index have large market capital and high liquidity [6], however, an optimal portfolio analysis is still needed to select stocks that are efficient as optimal portfolio formation. to observe optimal portfolio performance. This observation is carried out to determine how the optimal portfolio performance is at any time, so that it can become valuable information for investors in investing their capital. Therefore, this study is intended to investigate scientific studies related to the measurement 
of portfolio performance in the capital market in Indonesia so that a more comprehensive picture can be obtained.

\section{LITERATURE REVIEW Portfolio Theory}

In forming a portfolio, investors always want to maximize the expected return with a certain level of risk that they are willing to bear, or look for a portfolio that offers the lowest risk with a certain rate of return.

The essence of portfolio formation is to reduce risk by means of diversification [7], namely allocating a number of funds to various investment alternatives that are negatively correlated. In the theory of portfolio selection is how to select a portfolio of various assets, to maximize the expected return at a certain level of risk that investors are willing to bear.

\section{Efficient portfolio}

To form an optimal portfolio, investors must first determine an efficient portfolio. An efficient portfolio is a portfolio that provides the largest expected return with a certain risk and provides the smallest risk with a certain expected return[8]. A rational investor will choose this efficient portfolio because it is a portfolio formed by optimizing one of two dimensions, namely the expected return or portfolio risk.

\section{Optimal portfolio}

An efficient portfolio is not necessarily an optimal portfolio. An efficient portfolio has only one good factor, namely the expected return factor or the risk factor only. The optimal portfolio is a portfolio with the best combination of expected return and risk. Tandelilin, states that the optimal portfolio is a portfolio chosen by an investor from the many options available in a collection of efficient portfolios.

\section{Single Index Model}

The Single Index Model is a technique of measuring the return and risk of a stock or portfolio[9]. The single index method was developed by Sharpe. This method can be used to simplify calculations in the Markowitz method. In addition, the single index method can also be used to calculate the expected return and portfolio risk [4].

\section{Portfolio Performance}

Portfolio performance can be calculated based on portfolio returns only. Due to the trade off between return and risk, measuring a portfolio based on the return may not be sufficient, but it must be considered both the return and the risk. Measurements involving these two factors are called risk-adjusted returns [4]. One of the risk-adjusted return calculation models is reward to variability. This method measures portfolio performance by dividing the return over the variability of the portfolio return. The greater the reward to variability, the better the portfolio performance[4].

\section{RESEARCH METHODOLOGY}

This research is included in census research. The population is all companies whose shares are consistently included in the LQ45 index for the period February-July 2020 as many as 45 companies, while the subject or unit of analysis in this study is the daily closing stock price.

The type of data used is in the form of secondary data, namely the daily closing stock price and closing stock price index obtained from the Indonesia Exchange Monthly Statistics Data and Bank Indonesia Certificate interest rate data for the period 30 April - 30 June 2020.

Data analysis was performed using the Single Index Model and the Sharpe Index. The Single Index Model is used to determine the optimal portfolio set, while the Sharpe Index is used to measure the efficiency of the performance of the portfolio that has been formed with the Single Index Model. The calculations are performed using the Microsoft Excel program[10].

Analysis of optimal portfolio formation can be carried out in the following steps [4]:

1. Collecting data on stocks that are included in the LQ45 Index in the February-July 2020 period, namely daily closing price data.

2. Calculate stock returns with the formula: $\mathrm{R}_{\mathrm{i}, \mathrm{t}}=$ $\frac{P_{i, t}-P_{i, t-1}}{P_{i, t-1}}$

where:

$\mathrm{R}_{\mathrm{i}, \mathrm{t}} \quad$ : stock return i period $\mathrm{t}$

$\mathrm{P}_{\mathrm{i}, \mathrm{t}} \quad$ : share price i period $\mathrm{t}$

$\mathrm{P}_{\mathrm{i}, \mathrm{t}-1} \quad$ : stock price I period $\mathrm{t}-1$

3. Calculate the expected return with the formula: $\mathrm{E}\left(\mathrm{R}_{\mathrm{i}}\right)=\alpha_{\mathrm{i}}+\beta_{\mathrm{i}} \cdot \mathrm{E}\left(\mathrm{R}_{\mathrm{m}}\right)$.

where:

$\beta_{\mathrm{i}}=\frac{\sigma_{\mathrm{i}, \mathrm{m}}}{\sigma_{\mathrm{m}}^{2}}$

$\alpha_{\mathrm{i}}=\mathrm{E}\left(\mathrm{R}_{\mathrm{i}}\right)-\beta_{\mathrm{i}} \cdot \mathrm{E}\left(\mathrm{R}_{\mathrm{m}}\right)$

$\mathrm{E}\left(\mathrm{R}_{\mathrm{m}}\right)=\frac{\sum_{\mathrm{t}=1}^{\mathrm{n}} \mathrm{R}_{\mathrm{m}, \mathrm{t}}}{\mathrm{n}}$

$\mathrm{R}_{\mathrm{m}, \mathrm{t}}=\frac{\mathrm{IHSG}_{\mathrm{t}}-\mathrm{IHSG}_{\mathrm{t}-1}}{\mathrm{IHSG}_{\mathrm{t}-1}}$

where:

$\mathrm{E}\left(\mathrm{R}_{\mathrm{i}}\right)$ : expected return of stocks $\mathrm{i}$

$\beta_{\mathrm{i}} \quad$ : stock beta $\mathrm{i}$

$\alpha_{\mathrm{i}} \quad$ : stock alpha $\mathrm{i}$

$E\left(R_{m}\right)$ : the market's expected return

$\mathrm{R}_{\mathrm{m}, \mathrm{t}} \quad$ : period market return $\mathrm{t}$

$\sigma_{\mathrm{i}, \mathrm{m}} \quad$ : covariance of stock return i with market return

$\sigma_{\mathrm{m}}^{2} \quad$ : variants of market returns

IHSG $_{\mathrm{t}}$ : the composite stock price index period $\mathrm{t}$

$\mathrm{IHSG}_{\mathrm{t}-1}$ : the composite stock price index period $\mathrm{t}-1$

4. Calculate stock risk with a formula: $\quad \sigma^{2}{ }_{i}=\beta_{\mathrm{i}}{ }^{2} \cdot \sigma_{\mathrm{m}}{ }^{2}$

$+\sigma_{\mathrm{ei}}^{2}$

Where:

$$
\sigma_{\mathrm{m}}{ }^{2}=\frac{\left[\mathrm{R}_{\mathrm{m}, \mathrm{t}}-\mathrm{E}\left(\mathrm{R}_{\mathrm{m}}\right)\right]^{2}}{\mathrm{n}}
$$$$
\sigma_{\mathrm{ei}}^{2}=\sigma_{\mathrm{i}}^{2}-\beta_{\mathrm{i}}^{2} \sigma_{\mathrm{m}}^{2}
$$ 
where:

$\sigma_{\mathrm{i}}^{2} \quad$ : variance of stock return $\mathrm{i}$

$\sigma_{e, i}^{2} \quad$ : variance of stock residual i

5. Calculate the excess return to beta of each stock $\left(E B_{i}\right)$ with a formula: $\quad E R B i=\frac{E\left(R_{i}\right)-R_{f}}{\beta_{i}}$

Where:

$\mathrm{R}_{\mathrm{f}} \quad$ : risk free rate of interest

6. Order stocks based on the largest $\mathrm{ERB}_{\mathrm{i}}$ value to the smallest $\mathrm{ERB}_{\mathrm{i}}$ value.

7. Calculate the cut off point.

After ranking from highest to lowest based on $\mathrm{ERB}_{\mathrm{i}}$, the next step is to find the cut-off point and compare it with $\mathrm{ERB}_{\mathrm{i}}$. Shares that have $\mathrm{ERB}_{\mathrm{i}}$ that are greater than the cut-off point are included in the optimal portfolio.

$\mathrm{C}_{\mathrm{i}}=\frac{\sigma_{\mathrm{m}}^{2} \sum_{\mathrm{i}=1}^{\mathrm{n}} \mathrm{A}_{\mathrm{i}}}{1+\sigma_{\mathrm{m}}^{2} \sum_{\mathrm{i}=1}^{\mathrm{n}} \mathrm{B}_{\mathrm{i}}}$

Where:

$\mathrm{A}_{\mathrm{i}}=\frac{\left[\mathrm{E}\left(\mathrm{R}_{\mathrm{i}}\right)-\mathrm{R}_{\mathrm{f}}\right] \cdot \beta_{\mathrm{i}}}{\sigma_{\mathrm{e}, \mathrm{i}}{ }^{2}}$

$\mathrm{B}_{\mathrm{i}}=\frac{\beta_{\mathrm{i}}{ }^{2}}{\sigma_{\mathrm{e}, \mathrm{i}}{ }^{2}}$

Where:

$\mathrm{C}_{\mathrm{i}}$ : cut off point

8. Determine the optimal portfolio.

After knowing the ERB $B_{i}$ of each stock and sorted from largest to smallest, the next step is to compare it with the largest $\mathrm{C}$ value. This step is used to determine which each share has a greater $E B_{i}$ value, so the shares qualify for inclusion in the portfolio.

9. Determine the amount of the proportion of funds for each share selected by the following formula: $\mathrm{W}_{\mathrm{i}}=$ $\frac{\mathrm{z}_{\mathrm{i}}}{\sum_{\mathrm{i}=1}^{\mathrm{n}} \mathrm{z}_{\mathrm{i}}}$

Where:

$\mathrm{Z}_{\mathrm{i}}=\frac{\beta_{\mathrm{i}}{ }^{2}}{\sigma_{\mathrm{e}, \mathrm{i}}{ }^{2}}\left[\mathrm{ERB}_{\mathrm{i}}-\mathrm{C}^{*}\right]$

10. Calculate the portfolio's expected return, using the formula:

Where:

$\alpha_{\mathrm{p}}=\sum_{\mathrm{i}=1}^{\mathrm{n}} \mathrm{W}_{\mathrm{i}} \cdot \alpha_{\mathrm{i}}$

$\beta_{\mathrm{p}}=\sum_{\mathrm{i}=1}^{\mathrm{n}} \mathrm{W}_{\mathrm{i}} \cdot \beta_{\mathrm{i}}$

11. Calculating portfolio risk with formulas: $\sigma_{\mathrm{p}}{ }^{2}=\beta_{\mathrm{p}}{ }^{2}$ $\sigma_{\mathrm{m}}^{2}+\left[\sum_{\mathrm{i}}^{\mathrm{n}} \mathrm{W}_{\mathrm{i}} \sigma_{\mathrm{e}, \mathrm{i}}\right]^{2}$

12. Calculating the performance of a stock portfolio using the Sharpe Index. The formula used is as follows [11]:

$S_{p}=\frac{E\left(R_{p}-R_{f}\right)}{\sigma_{p}}$

Where:

$\mathrm{S}_{\mathrm{p}}$ : portfolio sharpe index

$\sigma_{\mathrm{p}}:$ the standard deviation of the portfolio

After calculating the amount of the Sharpe Index. Compared between the optimal portfolio formed from LQ45 shares with the JCI. The higher the Sharpe Index of a portfolio compared to other portfolios, the better the performance of the portfolio.

\section{RESULTS AND DISCUSSION Expected Return and Stock Risk}

A large return will motivate investors to continue investing and be ready to assume the risk of their investment. The calculation of individual stock returns is based on changes in the closing price per day during the month of May-June 2020. By entering stock returns in the calculation formula, the expected return and risk of individual shares are obtained. The results of the expected return in Table 1 show that there are negative and positive expected returns. Stocks that have a positive expected return are stocks that deserve to be used as an alternative in investing.

The stock with the highest expected return was BBTN shares with a value of 0.0111. However, the stock that has the smallest risk is GGRM stock with a value of 0.0172 . In investing, investors do not merely look at the amount of expected return or risk, but investors must consider the amount of risk borne which will provide a certain expected return, thus rational investors or investors who are risk averse to risk will choose stocks that have the smallest coefficient of variation are BTPS shares with a value of 3.83 .

\section{Systematic Risk}

Stock risk in a single index model consists of systematic risk $\left(\beta \mathrm{i}^{2} . \sigma \mathrm{m}^{2}\right)$ and unsystematic risk $\left(\sigma \mathrm{e}, \mathrm{i}^{2}\right)$. Investors have an interest in systematic risk, because unsystematic risk can be eliminated by diversification. The amount of systematic risk is the result of multiplying beta squared $\left(\beta \mathrm{i}^{2}\right)$ with market variance $\left(\sigma \mathrm{m}^{2}\right)$, the magnitude of the market variance for all stocks is the same, so the systematic risk of shares is measured solely by beta. Table 1 shows that the largest systematic risk is BBTN shares with a value of 3.3567 , while the smallest risk is KLBF shares with a value of 0.3091 .

The sensitivity of stock returns to market conditions is generally indicated by the beta coefficient. The beta coefficient can be positive or negative. If the beta is positive, then the increase in market returns will cause an increase in stock returns, conversely if the beta is negative, an increase in market returns will cause a decrease in stock returns. The size of the normal beta coefficient is $\beta=1$. If a stock has $\beta<1$ it is called a weak stock, which means that if there is an increase in market return of $\mathrm{X} \%$, then the stock return will increase by less than $\mathrm{X} \%$ and vice versa $\beta>1$ is called aggressive stocks, which means if the market return increases by $\mathrm{X} \%$, then the stock return will increase by more than $\mathrm{X} \%$ and vice versa.

The results of beta calculations in Table 1 show that all stocks have a positive beta and the highest beta value is 3.3567. This value means that a change in market return of $1 \%$ will result in a change in return of shares in the same direction of $3.3567 \%$. If the beta value is greater, 
the greater the influence of the market return on stock returns, so the higher the risk attached to the stock.

\section{Returns and Market variants}

The market index that can be selected for the Indonesia Stock Exchange market is the Composite Stock Price Index. In calculating the market return, the daily closing Composite Stock Price Index data is used during the month of May - June 2020. The calculation results show that the expected market return is positive, namely 0.0011 with a standard deviation of 0.0127 . If the expected market return and market beta are compared with the expected return and beta of 45 stocks that are members of the LQ45 Index, there are 33 company stocks that have an expected return above the market expected return and 30 stocks that have a beta above the market beta.

Market beta always has a value of 1 , because market beta is obtained from the quotient between market variants and market variants, namely $0.0002 / 0.0002=1$. Thus, stocks that have a beta greater than 1 mean that they have a higher risk than market risk.

Table-1: Calculation Results of Expected Return, Standard Deviation, Coefficient of Variation and Stock Beta

\begin{tabular}{|l|l|l|l|l|l|l|l|l|l|}
\hline Code & $\mathbf{E}\left(\mathbf{R}_{\mathbf{i}}\right)$ & $\boldsymbol{\sigma}_{\mathbf{i}}$ & $\mathbf{C V}_{\mathbf{i}}$ & $\boldsymbol{\beta}_{\mathbf{i}}$ & $\mathbf{C o d e}$ & $\mathbf{E}\left(\mathbf{R}_{\mathbf{i}}\right)$ & $\boldsymbol{\sigma}_{\mathbf{i}}$ & $\mathbf{C V}_{\mathbf{i}}$ & $\boldsymbol{\beta}_{\mathbf{i}}$ \\
\hline ACES & 0.0002 & 0.0264 & 156.31 & 0.946 & ITMG & 0.0001 & 0.0312 & 301.98 & 1.1234 \\
ADRO & 0.0028 & 0.0380 & 13.43 & 1.8683 & JPFA & 0.0062 & 0.0444 & 7.14 & 2.3598 \\
AKRA & 0.0022 & 0.0370 & 16.74 & 2.3243 & JSMR & 0.0098 & 0.0396 & 4.07 & 1.7398 \\
ANTM & 0.0050 & 0.0291 & 5.77 & 1.4841 & KLBF & 0.0006 & 0.0205 & 35.18 & 0.3091 \\
ASII & 0.0065 & 0.0319 & 4.93 & 1.7350 & LPPF & 0.0093 & 0.0595 & 6.41 & 2.6205 \\
BBCA & 0.0029 & 0.0256 & 8.70 & 1.2788 & MNCN & 0.0005 & 0.0402 & 83.16 & 1.2725 \\
BBNI & 0.0040 & 0.0445 & 11.22 & 2.8382 & PGAS & 0.0086 & 0.0431 & 5.02 & 2.5563 \\
BBRI & 0.0036 & 0.0391 & 10.95 & 2.2685 & PTBA & 0.0027 & 0.0374 & 13.78 & 1.2482 \\
BBTN & 0.0111 & 0.0595 & 5.37 & 3.3567 & PTPP & 0.0078 & 0.0384 & 4.92 & 2.2733 \\
BMRI & 0.0035 & 0.0363 & 10.45 & 2.3446 & PWON & 0.0035 & 0.0435 & 12.37 & 1.9245 \\
BRPT & -0.0054 & 0.0350 & -6.50 & 0.8699 & SCMA & 0.0083 & 0.0381 & 4.58 & 0.8415 \\
BSDE & 0.0024 & 0.0481 & 19.89 & 2.3923 & SMGR & 0.0056 & 0.0299 & 5.313 & 0.9781 \\
BTPS & 0.0110 & 0.0422 & 3.83 & 1.5470 & SRIL & 0.0050 & 0.0403 & 8.108 & 1.5630 \\
CPIN & 0.0058 & 0.0332 & 5.77 & 1.3449 & TBIG & -0.0018 & 0.0235 & -12.77 & 0.4863 \\
CTRA & 0.0041 & 0.0456 & 11.23 & 2.4413 & TKIM & 0.0018 & 0.0445 & 25.28 & 1.9988 \\
ERAA & 0.004 & 0.0311 & 84.17 & 1.4077 & TLKM & -0.0035 & 0.0211 & -6.03 & 0.8193 \\
EXCL & 0.0028 & 0.0297 & 10.67 & 0.4938 & TOWR & 0.0036 & 0.0206 & 5.72 & 0.3098 \\
GGRM & 0.0012 & 0.0172 & 13.84 & 0.3694 & UNTR & 0.0008 & 0.0271 & 34.78 & 1.5089 \\
HMSP & 0.0012 & 0.0278 & 22.82 & 0.9000 & UNVR & -0.0011 & 0.0194 & -18.16 & 0.5089 \\
ICBP & -0.0012 & 0.0226 & -18.57 & 0.4464 & WIKA & 0.0070 & 0.0367 & 5.24 & 2.2616 \\
INCO & 0.0028 & 0.0319 & 11.34 & 0.7147 & WSKT & 0.0048 & 0.0315 & 6.52 & 1.9248 \\
INDF & 0.0004 & 0.0273 & 72.47 & 0.4934 & RM & 0.0011 & 0.0127 & 11.14 & 1.0000 \\
INKP & 0.0026 & 0.0351 & 13.48 & 1.8188 & SBI & 0.0001 & 0.0000 & 0.03 & 0.0000 \\
INTP & 0.0011 & 0.0403 & 35.16 & 2.2270 & & & & & \\
\hline
\end{tabular}

Source: Secondary data processed (2020)

\section{Optimal Portfolio Formation}

The method used in the formation of the optimal portfolio of 45 stocks is a single index model. In selecting stocks to be included in a portfolio, certain criteria are needed. In a single index model, the first step that must be taken is to calculate the Excess Return to Beta value for each stock. In calculating the Excess Return to Beta, a risk-free rate of return $\left(R_{f}\right)$ is required. The risk-free rate of return is calculated based on the interest rate for Bank Indonesia Certificates. In this study, because the stock price used is the daily share price, the risk-free return is used in daily units. Based on data from Bank Indonesia Certificates for two months, starting from May-June 2020, the average interest rate is 0.0001 .

The results of the calculation of excess return to beta in Table 2 show that there are 39 stocks whose excess return to beta value is positive, while the other 6 stocks have a negative excess return to beta value. Stocks with a negative excess return to beta value means that the stock has a rate of return that is still below the risk-free rate of return. Therefore stocks that have a negative excess return to beta are not eligible to form an optimal portfolio. Meanwhile, 39 stocks that have a positive excess return to beta value have the opportunity to become part of the optimal portfolio. 
Table-2: Excess Return to Beta Calculation Results

\begin{tabular}{|l|l|l|l|l|l|l|l|l|}
\hline No & Code & ERB $_{\mathbf{i}}$ & No & Code & ERB $_{\mathbf{i}}$ & No & Code & ERB $_{\mathbf{i}}$ \\
\hline 1 & ACES & 0.0001 & 16 & ERAA & 0.0002 & 31 & PGAS & 0.0033 \\
2 & ADRO & 0.0015 & 17 & EXCL & 0.0054 & 32 & PTBA & 0.0021 \\
3 & AKRA & 0.0009 & 18 & GGRM & 0.0030 & 33 & PTPP & 0.0034 \\
4 & ANTM & 0.0033 & 19 & HMSP & 0.0012 & 34 & PWON & 0.0018 \\
5 & ASII & 0.0037 & 20 & ICBP & -0.0030 & 35 & SCMA & 0.0097 \\
6 & BBCA & 0.0022 & 21 & INCO & 0.0038 & 36 & SMGR & 0.0056 \\
7 & BBNI & 0.0014 & 22 & INDF & 0.0005 & 37 & SRIL & 0.0031 \\
8 & BBRI & 0.0015 & 23 & INKP & 0.0014 & 38 & TBIG & -0.0040 \\
9 & BBTN & 0.0033 & 24 & INTP & 0.0005 & 39 & TKIM & 0.0008 \\
10 & BMRI & 0.0014 & 25 & ITMG & -0.0000 & 40 & TLKM & -0.0044 \\
11 & BRPT & -0.0063 & 26 & JPFA & 0.0026 & 41 & TOWR & 0.0112 \\
12 & BSDE & 0.0010 & 27 & JSMR & 0.0056 & 42 & UNTR & 0.0004 \\
13 & BTPS & 0.0070 & 28 & KLBF & 0.0015 & 43 & UNVR & -0.0023 \\
14 & CPIN & 0.0042 & 29 & LPPF & 0.0035 & 44 & WIKA & 0.0030 \\
15 & CTRA & 0.0016 & 30 & MNCN & 0.0003 & 45 & WSKT & 0.0024 \\
\hline
\end{tabular}

Source: Secondary data processed (2020)

Thus, we need a limiting point that determines the limit of the excess return to beta value which is said to be high. This cut off point is shown in the last column (Ci) table 3 below.

Table-3: Excess Return to Beta Calculation Results

\begin{tabular}{|l|l|l|l|l|l|l|l|l|}
\hline No & Code & Ci & No & Code & Ci & No & Code & Ci \\
\hline 1 & ACES & 0.0021 & 16 & ERAA & 0.0021 & 31 & PGAS & 0.0035 \\
2 & ADRO & 0.0028 & 17 & EXCL & 0.0034 & 32 & PTBA & 0.0031 \\
3 & AKRA & 0.0023 & 18 & GGRM & 0.0034 & 33 & PTPP & 0.0035 \\
4 & ANTM & 0.0035 & 19 & HMSP & 0.0025 & 34 & PWON & 0.0031 \\
5 & ASII & $0.0036^{*}$ & 20 & ICBP & 0.0020 & 35 & SCMA & 0.0011 \\
6 & BBCA & 0.0031 & 21 & INCO & 0.0035 & 36 & SMGR & 0.0027 \\
7 & BBNI & 0.0025 & 22 & INDF & 0.0023 & 37 & SRIL & 0.0034 \\
8 & BBRI & 0.0029 & 23 & INKP & 0.0026 & 38 & TBIG & 0.0020 \\
9 & BBTN & 0.0034 & 24 & INTP & 0.0022 & 39 & TKIM & 0.0023 \\
10 & BMRI & 0.0027 & 25 & ITMG & 0.0021 & 40 & TLKM & 0.0020 \\
11 & BRPT & 0.0019 & 26 & JPFA & 0.0033 & 41 & TOWR & 0.0004 \\
12 & BSDE & 0.0025 & 27 & JSMR & 0.0034 & 42 & UNTR & 0.0022 \\
13 & BTPS & 0.0023 & 28 & KLBF & 0.0029 & 43 & UNVR & 0.0021 \\
14 & CPIN & 0.0035 & 29 & LPPF & 0.0036 & 44 & WIKA & 0.0034 \\
15 & CTRA & 0.0030 & 30 & MNCN & 0.0022 & 45 & WSKT & 0.0032 \\
\hline
\end{tabular}

Source: Secondary data processed (2020)

In the $\mathrm{Ci}$ column, the cut off point $(\mathrm{C} *)$ is at 0.0036 or in ASII stocks with an ERB value of 0.0037 , which is the last ERB value is still greater than the $\mathrm{Ci}$ value (Table 4). Thus, there are 9 stocks that meet the criteria to enter into the optimal portfolio formation. These stocks are TOWR, SCMA, BTPS, SMGR, JSMR, EXCL, CPIN, INCO and ASII.

Table-4: Cut off Point and Excess Return to Beta Calculation Results

\begin{tabular}{|l|l|l|l|l|l|l|l|l|l|}
\hline Code & TOWR & SCMA & BTPS & SMGR & JSMR & EXCL & CPIN & INCO & ASII \\
\hline $\mathrm{ERBi}$ & 0.0112 & 0.0097 & 0.0070 & 0.0056 & 0.0056 & 0.0054 & 0.0042 & 0.0038 & 0.0037 \\
$\mathrm{E}\left(\mathrm{R}_{\mathrm{i}}\right)$ & 0.0036 & 0.0083 & 0.0110 & 0.0056 & 0.0098 & 0.0028 & 0.0058 & 0.0028 & 0.0065 \\
$\sigma$ & 0.0206 & 0.0381 & 0.0422 & 0.0299 & 0.0396 & 0.0297 & 0.0332 & 0.0319 & 0.0319 \\
$\beta_{\mathrm{i}}$ & 0.3098 & 0.8415 & 1.5470 & 0.9781 & 1.7398 & 0.4938 & 1.3449 & 0.7147 & 1.7350 \\
$\alpha_{\mathrm{i}}$ & 0.0032 & 0.0074 & 0.0092 & 0.0045 & 0.0079 & 0.0022 & 0.0042 & 0.0020 & 0.0045 \\
$\sigma^{2} \mathrm{ei}$ & 0.0004 & 0.0013 & 0.0014 & 0.0007 & 0.0011 & 0.0008 & 0.0008 & 0.0009 & 0.0005 \\
$\mathrm{Aj}$ & 2.6461 & 5.1619 & 12.0990 & 7.3078 & 15.7685 & 1.5618 & 9.3525 & 2.0596 & 20.7457 \\
$\Sigma \mathrm{Aj}$ & 2.6461 & 7.8080 & 19.9069 & 27.2147 & 42.9832 & 44.5450 & 53.8976 & 55.9572 & 76.7029 \\
$\mathrm{Bj}$ & 236 & 530 & 1,718 & 1,299 & 2,821 & 290 & 2,231 & 546 & 5,656 \\
$\Sigma \mathrm{Bj}$ & 236 & 766 & 2,483 & 3,783 & 6,603 & 6.893 & 9,124 & 9,670 & 15,327 \\
$\mathrm{C}_{\mathrm{i}}$ & 0.0004 & 0.0011 & 0.0023 & 0.0027 & 0.0034 & 0.0034 & 0.0035 & 0.0035 & $0.0036^{*}$ \\
\hline
\end{tabular}

Source: Secondary data processed (2020)

\section{The proportion of the Share Fund}

After it is known that 9 stocks have been selected to enter into the optimal portfolio, then determine the proportion (wi) of the funds invested in each share in the portfolio. The amount of the proportion of funds invested in each share in the 
portfolio is as shown in the proportion column in table 5 , then it is plotted with 3D Pie type as shown in Figure 1.From this figure, it can be seen that the proportion of funds for each stock that makes up the optimal portfolio is TOWR is 0.26 , SCMA is 0.18 , BTPS is 0.17 , SMGR is 0.12 , JSMR is 0.15 , EXCL is 0.05 , CPIN is 0.05 , INCO is 0.01 and ASII is 0.01 .

Table-5: Optimal Portfolio Proportion

\begin{tabular}{|l|l|l|}
\hline No & Code & Proportion \\
\hline $\mathbf{1}$ & TOWR & 0.263 \\
$\mathbf{2}$ & SCMA & 0.175 \\
$\mathbf{3}$ & BTPS & 0.174 \\
$\mathbf{4}$ & SMGR & 0.123 \\
$\mathbf{5}$ & JSMR & 0.148 \\
$\mathbf{6}$ & EXCL & 0.048 \\
$\mathbf{7}$ & CPIN & 0.047 \\
$\mathbf{8}$ & INCO & 0.007 \\
$\mathbf{9}$ & ASII & 0.014 \\
\hline Total & & 1.000 \\
\hline
\end{tabular}

Source: Secondary data processed (2020)

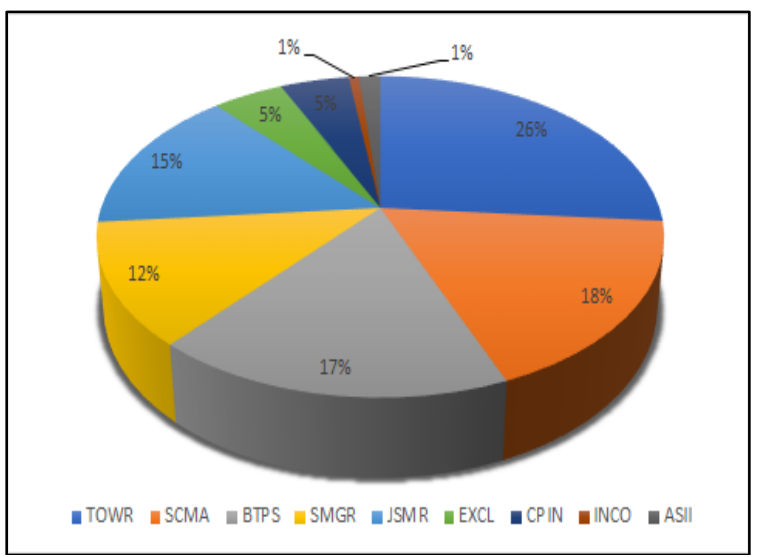

Fig-1: Optimal Portfolio Proportion Graph

\section{Expected Return and optimal portfolio risk}

The purpose of forming an optimal portfolio of stocks is to reduce risk by means of diversification. In this study, 9 stocks were found to be the optimal portfolio choices. This optimal LQ45 portfolio provides an expected return of 0.0070 per day and is much higher than the market expected return of 0.0011 . When compared with the expected return of each stock included in the optimal portfolio, there are three company stocks, namely SCMA, BTPS and JSMR which have an expected return greater than the optimal portfolio expected return. However, the three stocks of these companies have a greater risk than the portfolio risk (portfolio standard deviation), which is 0.0176 per day.

The results of this study are in line with portfolio theory, which states that portfolio theory is based on the observation that investors in the stock exchange diversify, because they want to reduce risk. Halim 12], explains that the more the number of shares in the portfolio, the less unsystematic risk. In addition, the results of this study also prove that the expected return and stock risk are more optimal if diversified than investing in one company stock, because the optimal portfolio formed from 9 stocks provides a coefficient of variation of 2.5199 (Table 6) smaller than the coefficient of variation. each share (Table 1).

\section{Portfolio Performance Evaluation}

Like an evaluation of a company's performance, a portfolio that has been formed also needs to be evaluated for its performance, in order to get a portfolio that produces the greatest return with a certain risk or vice versa. The LQ-45 portfolio index has a Sharpe index number of 0.3901 and the JCI has a Sharpe index of 0.0804. This shows that the performance of the LQ45 portfolio is better than the overall capital market performance shown by the Composite Stock Price Index.

Table-6: Portfolio Output

\begin{tabular}{|l|l|l|l|l|l|l|l|l|}
\hline $\boldsymbol{\alpha}_{\mathbf{p}}$ & $\boldsymbol{\beta}_{\mathbf{p}}$ & $\boldsymbol{\beta}_{\mathbf{p}} \mathbf{\sigma}_{\mathbf{m}}{ }^{2}$ & $\boldsymbol{\sigma E}^{\mathbf{2}}$ & $\boldsymbol{\sigma}_{\mathbf{p}}$ & $\mathbf{E}\left(\mathbf{R}_{\mathbf{p}}\right)$ & $\mathbf{C V}_{\mathbf{p}}$ & $\begin{array}{l}\text { Sharpe Index } \\
\text { LQ45 }\end{array}$ & $\begin{array}{l}\text { Sharpe } \\
\text { Index JCI }\end{array}$ \\
\hline $\mathbf{0 . 0 0 5 9}$ & 0.9928 & 0.0002 & 0.0002 & 0.0176 & 0.0070 & 2.5199 & 0.3901 & 0.0804 \\
\hline
\end{tabular}

Source: Secondary data processed (2020)

\section{CONCLUSIONS AND SUGGESTIONS}

Based on the calculations and analysis carried out, the conclusion of this study is that the optimal portfolio formed by a single index model has a good portfolio performance. This is because the optimal portfolio formed from stocks that are members of the LQ45 has a sharpe index of 0.3901 , which is greater than the JCI which has a sharpe index of 0.0084 .

Suggestions that can be considered for future researchers: First, comparing with the Markowitz method. Second, replace with the object under study.
Third, replace the portfolio performance evaluation method with the Trenor, Jensen or Sortino index.

\section{REFERENCES}

1. Tandelilin Eduardus, Portofolio dan Investasi Teori dan Aplikasi, Pertama. (2001). Yogyakarta: KANISIUS.

2. Sari, F. A., \& Nuzula, N.F. (2017). "pembentukan portofolio optimal dengan model indeks tunggal (Studi Pada Perusahaan Property, Real Estate And Building Construction Yang Tercatat Di Bursa Efek Indonesia Periode 2013-2015),” J. Adm. Bisnis, 4(1), 1-9. 
3. Husnan, S. (2015). Dasar-Dasar Teori Portofolio dan Analisis Sekuritas, Kelima. Yogyakarta: UPP STIM YKPN, Yogyakarta.

4. Hartono, J. (2017). Teori Portofolio dan Analisis Investasi, Kesebelas. Yogyakarta: BPFE.

5. Graha, I. M. D. R., \& Darmayanti, N. P. A. (2016). Analisis portofolio optimal model indeks tunggal pada perusahaan yang tergabung dalam indeks LQ45. E-Jurnal Manajemen, 5(2).

6. Susanti, \& S. (2009). "Analisis Pembentukan Portofolio Optimal Saham Dengan Menggunakan Model Indeks Tunggal (Studi Pada Saham LQ-45 di Bursa Efek Indonesia Periode Agustus 2009-Juli 2012)," USU, 2013.

7. Rahmasita, F. (2014). Pembentukan portofolio optimal dengan menggunakan single index model
(Studi Pada Saham-saham Sektor Industri Dasar dan Kimia Bursa Efek Indonesia periode 20112013). Jurnal Administrasi Bisnis, 16(1).

8. Elton, E., \& Grubber. (1977). "Risk Reduction and Portofolio Size: An Analytical Solution,” J. Bus. 50, 415-437.

9. Zubir, Z. (2011). Manajemen Portofolio: Penerapannya dalam investasi saham. Jakarta: Salemba Empat.

10. Hartono, J. (2014). Teori dan Praktik Portofolio dengan Excel. Jakarta: Salemba Empat.

11. Manurung, A. H. (2000). "Mengukur Kinerja Portofolio," Usahawan, 11(29); 4146.

12. Halim, A. (2005). Analisis Investasi, Kedua. Jakarta: Salemba Empat. 